politica, 37. årg. nr. 3 2005, 333-340

\title{
Erik Christensen
}

\section{"Den videnskabelige værdirelativisme i praksis" som led i studenteroprøret på IFSK ${ }^{1}$}

\begin{abstract}
På Institut for Statskundskab i Århus var den videnskabelige værdirelativisme i studiets første år en central del af statskundskabens teori og metode. Under studenteroprørets første fase blev denne videnskabelige doktrin brugt af de studerende til at fremme en debat mellem lærere og studerende om videnskabsteori, studiets målsætning og undervisningstilrettelæggelse. De studerende krævede, at værdirelativismen fik praktiske konsekvenser, ved at underviserne fremlagde deres værdigrundlag, og at der i undervisningen skete en maksimal konfrontation af værdiopfattelser. En konsekvens af den kritik blev, at undervisningen i politisk idehistorie i 1969-70 blev gennemført på grundlag af de studerendes valg af seminaremne, hvilket blev accepteret af Professor Erik Rasmussen og var helt i overensstemmelse med værdirelativismens anvisning af, hvorledes værdikonflikter kan løses. I forlængelse af den amerikanske sociolog Alvin W. Gouldners betragtninger kan værdirelativismen på instituttet tolkes som en bevidst/ ubevidst professionsideologi, der var med til at skabe et vist fælles videnskabeligt værdigrundlag og kollegialt sammenhold.
\end{abstract}

Den videnskabelige værdirelativisme, som især via Erik Rasmussens lærebog Komparativ Politik 1 (1968: 31-45) var en del af statskundskabens teori og metode, betød, at studenteroprøret på Institut for Statskundskab fik et helt særligt forløb. Studenteroprøret var videnskabeligt forbundet med opgøret med positivismen. Men med den videnskabelige værdirelativisme havde statskundskaben allerede gjort op med positivismen. Derfor herskede der ingen tro på en værdifri og neutral videnskab, som det delvis var tilfældet $\mathrm{i}$ andre fag. I statskundskaben anerkendte man på den ene side, at ingen værdier videnskabeligt kunne bevises undtagen i relation til andre formål eller ideer, og på den anden side, at værdier havde betydning i alle faser i forskningsprocessen, hvorfor man kunne kræve, at man i så vid udstrækning som muligt gjorde rede for sine værdipræmisser i sin forskning og formidling.

I det følgende vil jeg først komme med en historisk beretning om forløbet af den første fase i studenteroprøret på Institut for Statskundskab. Til slut vil jeg i tilslutning til den amerikanske sociolog Alvin W. Gouldners tanker om værdifrihed i sociologien tolke værdirelativismen på instituttet som værende bevidst/ubevidst skabt som en professionsideologi, der var med til at skabe et fælles videnskabeligt værdigrundlag, som på én gang var med til at tilvejebringe et vist kollegialt sammenhold og samtidig dannede grundlag for en værdimæssig politisk pluralisme blandt lærerne.

Da studenteroprøret dukkede op, viste det sig imidlertid, at denne videnskabelige doktrin også kunne bruges af de studerende til at fremme de værdimæssige diskussioner, de følte var påtrængende og interessante.

Den videnskabelige værdirelativismes anerkendelse af værdiers centrale betydning betød, at de statskundskabsstuderende tog afsæt i værdirelativismen i deres kritik af studiet, universitetet og samfundet i den første fase af studenteroprøret. 
Værdirelativisme kom derved i sin faktiske funktion til at virke som murbrækker for en spændende og frugtbar debat mellem lærere og studerende om både videnskabsteori, studiets målsætning og undervisningstilrettelæggelse i enkelte fag.

\section{Kritik af undervisningen: Stormøde, kritik af undervisningen, skabelse af et nyt debatorgan (SAMSNAK) og en instituthøring}

Studenteroprøret på Institut for Statskundskab startede i februar 1969. Studenternes kritik havde tre dimensioner: 1 . De $\varnothing$ nske de andre og mere aktiverende undervisningsformer, hvor de havde medbestemmelse. 2. De ønskede medbestemmelse i de styrende organer på universitetet. 3. De ønskede en debat af studiets og generelt af videnskabens rolle i samfundet.

På et studentermøde den 5. februar med deltagelse af ca. 100 studerende blev det besluttet at nedsætte kritiske grupper på alle undervisningshold samt at udgive et blad, SAMSNAK, for samfundsfags- og statskundskabsstuderende. ${ }^{2}$

Begrebet "kritiske grupper" var blevet introduceret i studenterbladet Montanus' februarnummer $1969 \mathrm{i}$ en artikel "Kritiske grupper - et nyt debatforum" skrevet af Mihail Larsen og Klaus Birkholm, som oplyste, at der i løbet af de sidste tre måneder var oprettet grupper ved fagene engelsk, medicin, sammenlignende litteratur, idehistorie, fransk, historie, musik, økonomi, dansk, statskundskab, russisk og psykologi. Målene var, 1. at sætte fagene til debat - målsætning og undervisningsformer. 2. De universitetspolitiske problemer - medbestemmelse - et statutudvalg. 3. Bevidstgørelse.

Den 6. februar udkom det socialdemokratiske tidsskrift $n b$, der blev udgivet af Frit Forum, DSU og Faglig Ungdom i Århus og med Svend Auken som redaktør, med et nummer, hvor man med overskriften "Professor-fors $\varnothing$ mmelser" nævnte eksempler på, at en række århusianske og københavnske professorer havde for$s ø \mathrm{mt}$ deres undervisning. Et af disse eksempler var tydeligvis rettet mod Erling Bjøl på Institut for Statskundskab, fordi han ofte opholdt sig i udlandet i forbindelse med sin journalistiske virksomhed for Politiken. ${ }^{3}$

Da Jyllands-Posten og Aktuelt de følgende dage refererede artiklen, skabte anklagerne opstandelse hos instituttets lærere, og der blev talt om de studerendes "heksejagt" på lærerne. Erling Bjøl afviste anklagerne i Aktuelt og udtalte samtidig, at han altid havde sørget for undervisning på tidspunkter, når han havde været på rejse, samt at der aldrig igennem studienævnet havde været fremført klager.

Selv om kritikken skabte røre blandt lærerne, besluttede et medarbejderm øde dog at lade to yngre lærere indgå i redaktionen af SAMSNAK (Lise Togeby samt A. Lund-Sørensen). I det første nummer af bladet skrev Niels Arnfred en lille artikel "Quo Vadis", hvor han skitserede målet for de kritiske grupper og begrundede de studerendes aktiviteter med henvisning til den alment accepterede værdirelativistiske forståelsesramme. Målet var at starte en generel målsætningsdebat dels om undervisningens tilrettelæggelse, indhold og mål, dels om studiets samfundsmæssige betydning. "Ingen på instituttet vil hævde, at vi kan dyrke værdifri statskundskab, hverken i forskning eller undervisning ... I praksis betyder dette (som bekendt) at vi må være opmærksomme på forskningen og undervisningens afhængighed af vore egne samfundsmæssige placeringer og hele indstilling." 
Parallelt med debatten om kritik af undervisningen og nye undervisningsformer foregik der forhandlinger om en ny statut for et fælles studienævn for samfundsfag og statskundskab, hvor de studerende krævede $50 \mathrm{pct}$. medbestemmelse. Studienævnet havde hidtil kun været et rådgivende organ, hvilket betød, at en række studienævnsrelevante sager blev afgiort i lærerfaggrupperne. ${ }^{4}$

Erik Rasmussen var en af de professorer, der tog de studerendes udfordringer op og afholdt et diskussionsmøde den 14. februar (SAMSNAK nr. 2, 24.2.1969, referent: Jens Jørgen Jensen). Udgangspunktet var artiklen i studenterbladet Montanus om nedsættelsen af kritiske grupper. Her blev de kritiske gruppers funktion i relation til ændring af undervisningsformen ivrigt diskuteret, og de studerendes ønsker om nye undervisningsformer vandt bred tilslutning (med bl.a. støtte fra Bo Kjems, Erik Christensen, Erik Nordahl Svendsen, Viggo Jonasen, Poul Nielson, Peter Nannestad, Bettina Heltberg, Jørgen Nue Møller og Svend Auken).

Den 11. marts blev så afholdt en stor instituthøring, hvor alle professorer, Erik Rasmussen, Erling Bjøl, Poul Meyer og H.P. Clausen sad i et panel sammen med amanuenserne Curt Sørensen, Jan Stehouwer, A. Lund-Sørensen og Mogens N. Pedersen. De blev udspurgt af en gruppe studerende bestående af Bettina Heltberg, Morten Kelstrup, Aage Frandsen og Lars Torpe. Her spillede målsætningsdebatten $\mathrm{og}$ debatten om værdirelativisme en stor rolle. Den blev især fremført af Morten Kelstrup, der ønskede at diskutere værdigrundlaget for fagene og studiet som helhed (SAMSNAK. Ekstranummer marts 1969 med referat af høringen den 11.3., referent: Rikke Kjær). Erik Rasmussen erklærede sig her meget langt enig i Kelstrups redegørelse og "anså det for nødvendigt, at indføre studenterne i hele værdirelativismediskussionen for at gøre det klart, at objektiv forskning er umulig".

\section{Kritik af videnskaben: Debatoplægget:}

\section{"Videnskabelig værdirelativisme - også i praksis?"}

Kort efter høringen udgav Morten Kelstrup i samarbejde med den kritiske gruppe om studiets målsætning et lille skrift med titlen: "Videnskabelig værdirelativisme - også i praksis?" (16.3.1969. Morten Kelstrup i samarbejde med den kritiske gruppe om studiets målsæatning). I dette skrift lå i høj grad en tilslutning til den videnskabelige værdirelativisme, der blev forstået således:

1. Man kan ikke slutte fra er til bør. Det betyder, at såfremt ens konklusioner er vurderende, må man have én eller flere (eksplicitte eller implicitte) vurderende præmisser.

2. Man kan som videnskabsmand beskæftige sig med værdiernes indbyrdes forhold, og man kan lægge forskellige værdier til grund for sit videnskabelige virke. Derimod kan man ikke qua videnskabsmand (dvs. ved at anvende den videnskabelige metode) afgøre, hvad der er værdifuldt.

3. Det er ikke muligt i praksis at skelne skarpt mellem beskrivende og vurderende udsagn. Men sondringen kan opretholdes på et andet (logisk?) plan. Og det hører til videnskabelig hæderlighed, at man stræber efter at gøre sit værdigrundlag og sit værdisigte så klart som muligt. 
Det var specielt vedrørende det sidste punkt, de studerende følte, at lærerne og instituttet svigtede i praksis. Ved høringen havde flere af professorerne om deres vardigrundlag sagt, at de "stort set er tilfredse med det bestående", og at grundlaget var de fire gamle partiers opfattelse. Det var et prisværdigt om end lille skridt i retning af klargøring af værdigrundlaget. Men svaret var dog ifølge de studerende utilfredsstillende på flere måder: 1 . De bestående værdier er ikke entydige. 2. Man siger ikke noget om, hvordan forholdene kunne være. 3. Man hylder værdiproblemet som noget helt individuelt. 4. Det kommer til at fungere mere som en tilsløring end en afsløring.

Hvad man ifølge de studerende måtte kunne kræve var "en maksimal konfrontation af synspunkter". Det betød, at "ikke at konfrontere sit værdigrundlag med andres bør regnes som lige så videnskabeligt uhæderligt som det at ville påtvinge andre en viden uden at klargøre, hvorledes og med hvilken sikkerhed, man har erhvervet den." Den implicitte accept af "bestående værdier" og den manglende konfrontation mellem forskellige værdiopfattelser bet $\varnothing \mathrm{d}$, at man indirekte ved stofudvælgelse og problembehandling beskæftiger sig med det ikke kontroversielle, det konfliktløse og harmoniske. "Videnskaben får en funktion som ideologierstatning: at tilsløre og bygge bro over konflikterne."

Konsekvenserne af den manglende klargøring af værdigrundlaget for statskundskabsstudiet medførte, at: 1. Der er en fare for indoktrinering. 2. Der er en fare for, at videnskaben kommer til at fungere som ideologierstatning - at legitimere magthaverne. 3. Der er fare for, at studiet af politik vanskeliggøres for de studerende, der er kritiske. Derfor endte det kritiske papir om værdirelativismen med at kræve:

1. At undervisere og forskere skulle tvinges til at gøre deres værdigrundlag klart og eksplicit.

2. At der burde ske en maksimal konfrontation af værdiopfattelser i undervisningen.

3. At studiet af statskundskab ikke kun vedrørte kausalteori, men også værditeori.

4. At der burde være større muligheder for valg af seminarer.

5. At man fik nogle mere aktiverende undervisningsformer, hvor diskussioner af værdiopfattelser kom frem.

\section{Kritikken omsat i praksis i undervisningen i politisk idehistorie 1969-1970}

I foråret 1969 blev de nye undervisningsformer med medbestemmelse afprøvet inden for Erik Rasmussens fag, politisk idehistorie. Det var dengang placeret som et anden dels fag over to semestre, hvor man i det første semester gennemgik idehistorien kronologisk på grundlag af George H. Sabines grundbog, A History of Political Theory (1968) samt nogle originaltekster, og i det følgende semester afholdt et seminar på grundlag af et valgt emne.

Til et planlægningsmøde i maj 1969 havde de studerende på forhånd udarbejdet en detaljeret plan både for afviklingen af første og andet semester. ${ }^{5}$ De studerendes forslag til emne for seminar i foråret 1970 var "Velfærdsstatens idékompleks - ideologierne (ien) bag velfærdsstaten". Begrundelsen for valget af dette emne var ønsket om at gøre idehistorien mere relevant, således "at man i langt højere 
grad kunne komme til den individuelle afklaring af sit værdigrundlag, der ud fra en værdirelativistisk opfattelse er en forudsætning for al god videnskab".

På planlægningsmødet skete valget af seminaremne imidlertid først efter en længere debat, fordi Erik Rasmussen til mødet kom med et forslag om at behandle revolutionsteorier. Han regnede antagelig med, at de "oprørske" studerende var specielt interesserede i revolutionsteorier. Men de var mere interesserede $\mathrm{i}$ at kaste kritisk lys på det dominerende værdigrundlag (deres lærers værdigrundlag) i samfundet. Hvorledes afgøres en sådan uoverensstemmelse mellem værdier? Man forsøgte først at argumentere sig til rette. Men da det ikke kunne løse uenigheden, blev den meget eksemplarisk afgjort ved en demokratisk afstemning blandt de studerende, hvor der viste sig et stort flertal for valget af et seminar om velfærdsstatens ideologi. Denne løsningsmåde af værdiuoverensstemmelser var blevet skitseret i debatoplægget om den videnskabelige værdirelativisme i praksis. $\mathrm{Og}$ som bemærket her var en accept af en sådan demokratisk løsning af uoverensstemmelser ikke vanskeliggjort ved den videnskabelige værdirelativisme ifølge Erik Rasmussens Komparativ Politik 1 (1968: 31). Som god demokrat bøjede Erik Rasmussen sig for flertallet og arbejdede loyalt med at realisere seminaret. Han udarbejdede således senere et oplæg til seminaret, der skitserede en række problemstillinger, som man kunne beskæftige sig med. ${ }^{6}$

Erik Rasmussen var godt rustet til opgaven. Han havde nemlig i foråret 1969 holdt seks forelæsninger om ideologi og politik i radioens Søndagsuniversitet, som blev udgivet af Gyldendal i efteråret 1969. Heri havde han i et kapitel behandlet velfærdsdemokratiet og ungdomsoprørets ideologi (Rasmussen, 1969).

\section{Værdirelativismen som en minotaur: et dobbeltsidet væsen}

Denne lille historie viser, at den videnskabelige værdirelativisme som doktrin også må forstås i forhold til den sociale kontekst, den er opstået og har fungeret i. Det er ikke nok at forholde sig til den rent logisk filosofisk. Man må også se på de omstændigheder, den er opstået under, og på, hvorledes den er blevet fortolket, efterlevet, og hvilke funktioner den har haft.

Som allerede antydet indledningsvis mener jeg, at doktrinen om den videnskabelige værdirelativisme i instituttets første år især fungerede som en professionsidelogi, der skabte et vist kollegialt sammenhold, samtidig med at den sikrede en vis værdimæssig pluralisme. Den blev så under studenteroprørets første fase brugt som platform for en studie- og videnskabskritik.

At et sådant skift i funktion for videnskabelige doktriner kan ske, bekræftes af den amerikanske sociolog Alvin W. Gouldners eksemplariske analyser af værdifrihedsdoktrinens ${ }^{7}$ skiftende funktioner i sociologiens historie. Gouldner siger, at værdifrihedsdoktrinen, stammende fra Max Weber, har haft en mytisk karakter som en minotaur: et dobbeltsidet uhyre. En minotaur er et græsk uhyre med et tyrehoved og en menneskekrop.

Gouldners synspunkt er, at man kan betragte værdifrihedsideologen som en del af en professionsideologi (en gruppemyte), som kan have meget forskellige funktioner (positive eller negative) alt efter konteksten. Han mener således, at Webers oprindelige doktrin skal forstås som en beskyttelse af videnskabens integritet og 
frihed fra den tyske stat, dels som et redskab, der kunne skabe en slags modus vivendi for omgangen mellem videnskabsmænd indbyrdes blandt andet ved at sikre ro i det akademiske hus og reducere lærernes konkurrence om studenter.

Men doktrinen er ifølge Gouldner så åben, at den har sine dyder og laster. Den inviterer til at understrege adskillelsen og ikke den gensidige forbindelse mellem beskrivelser og vurderinger. Gouldner mener således, at til den negative side hører, at den både kan være nyttig for forskere, der ønsker at "flygte fra verden", og for dem, som ønsker at "flygte ind i den".

Med det mener han sociologer, som lever af sociologien snarere end lever for sociologien. Det er dem, der tænker på at skabe sig et job, som kan bruge nogle neutrale teknikker, som kan sælges og bruges i samfundet. Men det gælder også de videnskabsmænd, som "flygter fra verden", som ekskluderer sig fra det større samfund som en selvpålagt pligt, snarere end som en ydre pålagt begrænsning. Nogle af dem kaster sig i stedet for over en, hvad Gouldner kalder "kannibalistisk kritik af sociologien selv", som æder sig selv op i en "metodologisk kritik".

Gouldner taler om, at der på den måde nærmest kan ligge en uudtalt overenskomst mellem universitet og samfund, hvor universitetet af samfundet făr autonomi, og forskerne som en slags modydelse afstår fra at udtrykke deres kritik.

Konkret kæder Gouldner værdifrihedsproblematikken sammen med tendensen til professionalisering af sociologien, hvor man kan have en erhvervsmæssig interesse i at fralægge sig et moralsk ansvar i samfundet. Således forstået mener han, at myten er skadelig i en forsknings- og uddannelsesmæssig sammenhæng, hvis lærere ikke har lov og ligefrem en forpligtelse til at udtrykke deres personlige værdier. Hvis det bliver den dominerende holdning, vil der efter hans opfattelse for alvor blive mulighed for manipulation, og det vil skade videnskaben og kreativitetens udvikling.

\section{Afslutning}

Værd at bemærke afslutningsvis er imidlertid også, at det kun var i starten af studenteroprøret, at den videnskabelige værdirelativisme af de kritiske studenter på Institut for Statskundskab blev accepteret som en idemæssig platform for debat af studiet og samfundet. Relativt hurtigt blev store dele af oprøret præget af den kritiske teori og forskellige neo-marxistiske teoriers analyser af samfundsvidenskabens rolle og funktioner. Et tidligt udtryk for den tendens var Karen Helveg Petersens speciale: "Vardifrihedsproblematikken. En redegørelse for den senere tids tyske drøftelse af værdifrihedsproblematikken i samfundsvidenskaberne" (1969), der blev udgivet af det centrale studenterråd ved Aarhus Universitet, og som diskuterede Frankfurterskolens syn på problemet (se også Petersen, 1969).

Den i første fase frugtbare faglige og pædagogiske debat blev siden afløst af en periode med skabelse af en mere kritisk-ideologisk studentersubkultur, der begyndte at drive ideologikritisk arbejde. ${ }^{8}$ Senere krævede de kritiske studerende undervisning i marxistisk økonomi, som blev imødekommet, og flere år efter (i 1977) kom det endda til en regulær institutbesættelse sammen med mange andre institutter i forbindelse med regeringens indgreb over for Roskilde Universitetscenter. Men set $\mathrm{i}$ forhold til flere andre steder forblev Institut for Statskundskab et forholdsvis 
roligt sted under studenteroprøret. Her skete ingen paladsrevolutioner, og forskellige former for opposition blev behændigt både inkluderet og ekskluderet.

\section{Noter}

1. Institut for Statskundskab, Aarhus Universitet.

2. SAMSNAKs første nummer 14.2.1969. Blad for Statskundskab og samfundsfagsfolk. På daværende tidspunkt var der ca. 500 statskundskabs- og samfundsfagsstuderende.

3. SAMSNAK nr. 1. 1969, Morgenavisen Jyllands-Posten den 7.2.1969 ("Angreb pr. signalement på fem professorer"), Aktuelt den 8.2.1969 ("Unge i Århus hævder: De lærde pjækker"). Demokraten den 9.2.1969 ("Professorafsløringerne er en hån imod alle arbejdere"). Svend Auken erklærede senere (Montanus nr. 5. Maj 1969), at det aldrig havde været hensigten at drive hetz. Sagen blev dog ført helt op i folketingssalen, idet det århusianske socialdemokratiske folketingsmedlem Peter Jørgensen stillede spørgsmål til undervisningsminister, Helge Larsen, om, hvad han agtede at foretage sig for at effektivisere undervisningen på universiteterne specielt i relation til visse professorers arbejdsindsats. Undervisningsministeren henviste til, at sagen blev taget op på Aarhus Universitet (Folketingstidende. Forhandlingerne i Folketingsåret 1968-69: sp. 41624164).

4. I foråret 1969 afholdt studenterrådet en urafstemning blandt alle studerende om nye statutter for Aarhus Universitet. Et udvalg var kommet med to forslag, det ene forslag fra lærerflertallet og et fra studentermindretallet. Det sidste krævede medbestemmelse på 50 pct. i alle organer. Lærerne ville kun give $50 \mathrm{pct}$. i studienævn, men ikke i institutråd og fakultetsråd. Ved denne afstemning havde scient.pol/samfundsfag den højeste stemmeprocent på 67,3 pct. af alle studentergrupper på universitetet - hvoraf hele $77,3 \mathrm{pct}$. stemte for studentermindretallets krav om $50 \mathrm{pct}$. medbestemmelse $\mathrm{i}$ alle organer. Kun de konservative studerendes liste (G) repræsenteret ved Lars P. Gammelgaard anbefalede et nej. Der var en stemmeprocent på 53,3 pct. (Montanus nr. 4. april 1969).

5. Idehistorieundervisningen (Maksimum) (Erik Christensen) og Oplæg til gennemgang af Politisk idehistorie (maksimum) 1969-70. 21.5.1969 (Niels Arnfred, Flemming Arentoft og Erik Christensen)

6. Seminar vedr. velfærdsdemokrati, forår 1970. ER. Til seminaret blev skrevet opgaver om: Artikulerede og latente ideologier (Bo Kjems og Erik Nordahl Svendsen), Videnskab som ideologierstatning del I (Anders Lundkvist), Videnskaben som ideologierstatning del II (H. J. Højlund), Er ideologierne døde? (Erik Christensen), Liberalismen i det 20. århundrede (Kurt Egedal Christoffersen, Jørgen Saandvig Rasmussen), "Højreorienteret" kritik af velfærdssamfundet (Ulrich Thomassen), "Venstreorienteret" kritik af velfærdssamfundet (K.E. Andersen, Niels Olav Jensen), Generelt om velfærdsdemokratiets ideologi (Klaus Frimodt, Poul Hoiness, Palle Svensson), Socialdemokratismen i det 20. århundrede (Lone Mørup), Velfærdsstatens samfundsvidenskab og udviklingslandene. Tre artikler af Sweezy, Frank og Myrdal, forsynet med en indledning (Niels Arnfred), Den økonomiske velfærdsteori (Niels Albertsen), Politisk socialisering i velfærdsdemokratierne (Bjarne Christiansen).

7. Gouldner analyserer værdifrihedsideologien. Jeg overfører her hans synspunkter på værdirelativisme-doktrinen.

8. Det kom bl.a. til udtryk i Politicas særnummer om imperialisme, 4. årgang, nr. 1-2, 1971.

\section{Litteratur}

Folketingets Forhandlinger 1968-69.

Gouldner, Alvin W. (1973). "Anti-Minotaur: The Myth of a Value-Free Sociology", pp. 3-26 in Alvin W. Gouldner, For Sociology, New York: Basic Books, Inc. Publishers. 
Petersen, Karen Helveg (1969). ’Hvad er politisk videnskab?", Politica, 2. årgang, nr. 3.

Rasmussen, Erik (1968). Komparativ Politik 1, København: Gyldendal.

Rasmussen, Erik (1969). Ideologi og politik, København: Gyldendal.

Sabine, George H. (1968). A History of Political Theory, 3rd ed., London: George G. Harrap \& Co. Ltd. 